\section{Territory: Universe \\ (Translexical Opacity)}

\section{Wong Bing Hao}

Writing on gender is an elastic, sometimes even impenetrable and untranslatable, endeavour. Wong articulates the arcane lexical opacity of writing on trans and gender non-conforming experiences through the work of Jamie Crewe, Sophia Al-Maria and Victoria Sin, and Amy Lien and Enzo Camacho.

Writing on gender is an elastic, sometimes even impenetrable and untranslatable, endeavour. Universes are the territory of gendered language, text, exegesis, and communication: each a cosmos of bliss. Through readings of contemporary art practices, I hope to articulate the arcane lexical opacity of writing on trans and gender non-conforming experiences.

\section{$\mathrm{NW}$}

In their chapbook, Glaire (2017), artist and writer Jamie Crewe digitally scanned scenes from the 1908 French play Une leçon à la Salpêtrière, written by André de Lorde, using
OCR (optical character recognition) and subsequently subjected the identified characters to Google Translate. The result is a haphazard, often incoherent, text peppered with illegible combinations of letters and symbols. Posttranslation, the play's protagonist, Claire, a 'hysteric', is seldom indicated by her correct name. She is arbitrarily interpellated as 'Clear', 'Clmre', and a variety of other incomprehensible symbols. The translation process also confuses her gender, identifying her by all manner of gender pronouns - some known to us, others not yet. Her speech also becomes contorted and illogical.

Crewe's translations ironically shore up Claire's (allegedly) schizophrenic subjectivity.

Likewise, in a sketch they did for the chapbook, Crewe 'graffitied' in crimson ink an illustration of Rachilde's Monsieur Vénus, another text that they have investigated thoroughly for the exhibition, 'Female Executioner', at Gasworks, London in 2017. Dripping blood-red, Crewe's textual annotations on the pained figures detail the discomfiting side effects (lumps, mood swings, general aches) of taking oestradiol, an oestrogen steroid hormone. In Crewe's illustration, text on transness seems to excrete in excess from the abjected body.

Through seemingly degenerative artistic gestures, Crewe's practice births other worlds of meaning, suggesting new languages, embodiments, and paradigms of gender to spectators and readers. Here, incoherence, gore, and unknowability signal infinite possibilities rather than failure or inaptitude. Through deliberately unpredictable (mis)translations, Crewe sabotages determinacy and teleology. They deftly unravel the false sense of security inherent in our current linguistic and textual vocabularies, showing that they can (and should) indeed move beyond any fixed worldview or scope of intent. 


\section{$\underline{\text { TERMS }}$}

I AM NOT A MAN. DO NOT ADDRESS ME AS A MAN, OR REFER TO ME AS 'HE', 'HIM', 'LAD', 'BOY' OR ANY OTHER MASCULINE SIGNIFIER. REFERRING TO ME IN THIS WAY WILL RESULT IN TOTAL WITHDRAWAL. IF FAMILY MEMBERS REFER TO ME AS 'HIM' 'HE', ETC., YOU MUST CORRECT OR CHALLENGE THEM. THE CONSEQUENCE OF FAILING TO DO SO IS MY TOTAL WITHDRAWAL. IF I ALLOW YOU TO TOUCH MY BODY IN ANY WAY, YOU ARE NOT TOUCHING A MALE BODY. I DO NOT CONSENT TO GAY SEX. IF YOU HAVE GAY SEX WITH ME I WILL KNOW AND I WILL WITHDRAW TOTALLY. IF YOU, AT ANY TIME, UNDERSTOOD ME AS A MAN (OR 'BOY', 'LAD', ETC.) YOU WERE MISTAKEN. IF YOU MANIPULATED ME INTO SEX OR A RELATIONSHIP BASED ON YOUR UNDERSTANDING OF ME AS, FOR EXAMPLE, A GAY PUNK, OR A CHUBBY TEENAGED BOY, YOU WERE MISTAKEN. UPDATE YOUR RECORDS ACCORDINGLY AND RETURN TO ME MY POSSESSIONS. NOTHING I DO IS SYMPTOMATIC OF ANY FORM OF FLAMBOYANT MALENESS YOU MAY HAVE ENCOUNTERED OR IMAGINED. REGARDING ME AS MALE FOR ANY REASON, INCLUDING IN THIS WAY, REPRESENTS A FATAL BREACH OF OUR ENGAGEMENT AND WILL SEND ME FLEEING INTO THE GORSE. IF I HAVE HAD CAUSE TO, FOR EXAMPLE, HIDE UNDER A SLEEPING BAG AT YOUR APPROACH, OR RUN BAREFOOT INTO A LOCAL CEMETERY WHEN YOU WALK THROUGH THE FRONT DOOR, YOU ARE NEVER ALLOWED TO SEE ME, YOU ARE NEVER ALLOWED TO TALK TO ME, I WANT YOU TO KNOW NOTHING ABOUT ME. IF I FIND THAT YOU HAVE SEEN ME OR KNOW ANYTHING ABOUT ME, AND ESPECIALLY IF YOU EVER TRY TO TALK TO ME, I WILL RETREAT INTO HELL.

Jamie Crewe, Terms, 2018, text, digital prints on

paper. Courtesy of the artist and Tramway, Glasgow.

At the heart of Crewe's inquiry into text and its forms is gender. In another recent text-based work, Terms (2018), shown at Tramway, Glasgow, Crewe lays out, with no uncertainty and admirable fortitude, rules and regulations for how to treat them as a trans person. 'I AM NOT A MAN', the text announces its arrival fiercely, unequivocally. As its title suggests, this work is direct, contractual, and austere in its demands for its maker's ontological autonomy and legitimacy. It is necessarily and ordinately harsh, unburdening from trans people the responsibility and risk of revelation while granting them infernal agency. In Crewe's thoughtful work, text and subjectivity, intertwined, propose alternate registers, spacetimes, and dimensions of value, vascularizing their spectators' understanding and interpretations of gender.

It is not demanding to demand proper gendered pronouns. Contrary to misguided popular belief, this injunction is not just meant to enhance superficial knowledge and lexical literacy. It is a salvo toward becoming seen and identified as we are: celestial avatars, vaporous hoards, million-strong multitudes. From basal to cosmological levels, text transcends itself its meaning, logic, and symbols. For trans and gender non-conforming people, text is a utilitarian index, a portal to echelons where we are allowed to convalesce and coalesce without disturbance.

\section{WW}

$B C E$ (2018), a collaborative video directed by Sophia Al-Maria and written and performed by Victoria Sin, begins with the title's letters individually visualised as constellations. The letters' contours are light-links between stars, each a universe in its own right. Sin's torso, dim at first and then gradually lit in pops of cyborgian fluorescent light like an artificial star, is positioned at the centre of what appears to be a glittering planetary system. Their face is similarly bejewelled, complemented by the luxurious, cascading silver jewellery on their translucent blouse. On their face, there is a starshaped mole from which light projects and vibrates. But this powdery sheen of an illusion is exposed by the ecru quarter of their face which is cosmetically nude: an imperfect hagiography.

Commissioned by the Whitechapel Gallery, London, $B C E$, which alludes to the chronological period 'Before Christ,' is a queer feminist creation myth that departs from any known conceptual premise or body of knowledge on genesis narratives. In the video, each enunciation of 'god' is a glitch, remixed and redacted in order to vault spectators into the word's other worlds and possibilities of meaning. Through Sin and Al-Maria's artistic evocations, saints, and the names we call them by, are hollowed and intentionally misplaced. 


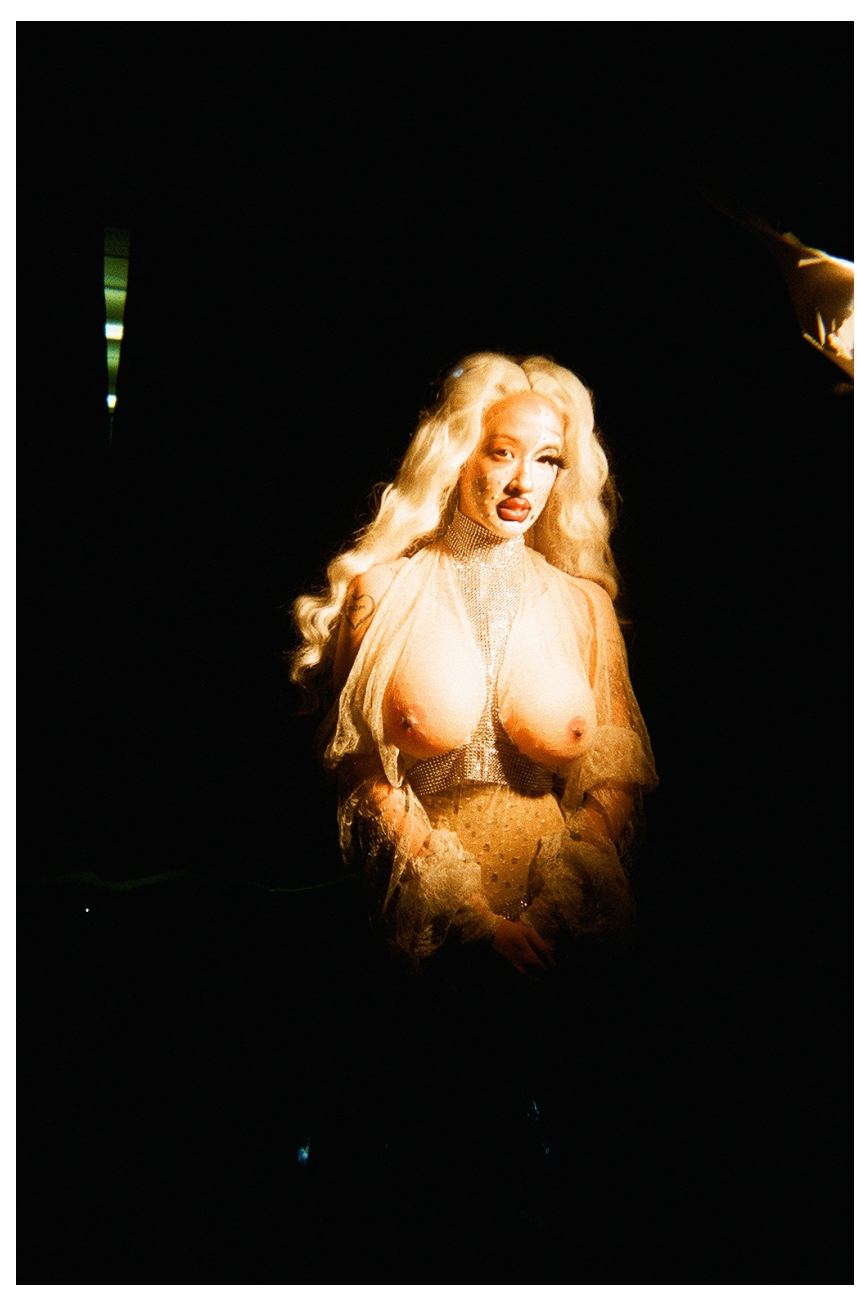

Victoria Sin and Sophia Al-Maria, BCE, 2019, video. Photo: Bernice Mulenga. Courtesy of Bernice Mulenga.

Together, the video's extra-terrestrial aesthetics and speculative writing propose a past and future without man-made tyranny, full of desire and potential. As Sin reiterates in the video: 'How many stars / How many worlds / How many ways of being alive?' Being in other worlds begins not with lofty ideals or theories of gender, but with oneself, one's body: 'As if I am not within me infinite versions of myself / As if one person could only be one thing'. Eschatologically, $B C E$ tracks different lineages, different Christs. But in Sin and Al-Maria's genealogical innovation, 'The end of the world was [both] a refusal and an offering'. $B C E$ is the artists' liturgy of dark, regenerative religiosity.

In a new performance, If I had the words to tell you we wouldn't be here now (2019), commissioned by Chi-Wen Gallery and presented during the Taipei Dangdai art fair, Sin continues to explore the multitudes of termination in gendered language. They use the deathly futility of textual and verbal communication to their advantage. Playing with excess, they inundate spectators with pronouns and descriptions (or, more accurately, attempts at descriptions) of gendered infinities. In Sin's performance, words trip over one another, failing to 'express' or 'explain' - articulating both the violence of gendered interpellation and the impossibilities of its attempted expansiveness. Linguistic communication is an exercise in both mastery and multiplicity. Protracting both experiences, Sin replaces factual certainties and information with the musical interventions of a pipa (a Chinese stringed instrument), irrupting spectators' processes of knowledge acquisition while hinting furtively at the communicative potential of adumbration.

\section{WW}

Amy Lien and Enzo Camacho's Lecture notes on Alfonso Ossorio's 'Angry Christ' mural in the Victorias Milling Company complex (1950) (2018) is a re-envisioning of Filipino-American abstract artist Alfonso Ossorio's famed mural at the Chapel of St. Joseph the Worker in Victorias City on Negros Island, the Philippines. Presented at the NTU Centre for Contemporary Art (NTU CCA), Singapore, Lien and Camacho's nascent project comprised a lecture, delivered in December 2018, and a mural-installation that served as a visual retracing, a rough replica, of a key section of Ossorio's mural and also as a canvas on which they annotated notes from their lecture. Research, embodied in their delivery of the lecture and the hand-made accretions onto Ossorio's original work, is an integral component of their project.

Upon encountering the iconicity of Ossorio's sprawling imposing mural, Lien and Camacho 
read it as a 'multivalent cipher', one that can be reprogrammed and dilated in its meanings. [1] Their project flexes language - spoken, written, drawn, represented - to convey forgotten or effaced aspects of Ossorio's life and artistic practice. Meticulously culled by Lien and Camacho, information - on such diverse topics as Philippine presidents and the Visayan Islands' artistic networks - flows through the figurative veins of their resurrected Angry Christ, congested in some parts, crossed through in others. At the centre of the mural is a prompter, which runs Lien and Camacho's complete lecture in bright red letters, a stand-in heart of sorts: the artists' generous cerebral provision. Words inundate and overwhelm, attesting to the complexity of Ossorio's life, as well as Lien and Camacho's inquiry into his life.

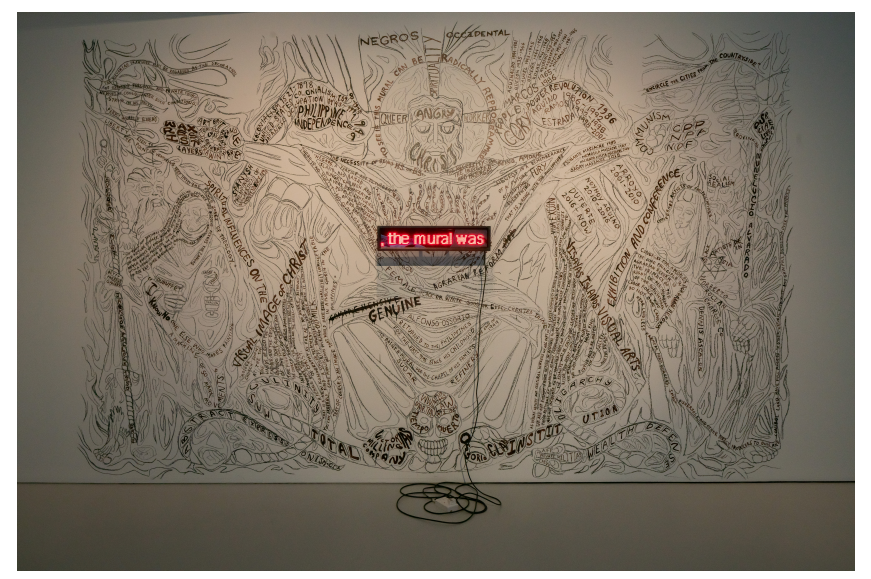

Amy Lien and Enzo Camacho, Lecture notes on Alfonso Ossorio's 'Angry Christ' mural in the Victorias Milling Company complex (1950), 2018, LED sign, real/imitation blood, molasses, semen, soil, and sweat. Courtesy of NTU Centre for Contemporary Art, Singapore.

Lien and Camacho's speculative project goes far beyond a literal, visual translation of Ossorio's life and artwork. Besides being a historical re-enactment of Ossorio's mural, one that necessarily makes amendments and additions to the sanctified original, Lien and Camacho use text to make various other productive transferences. For instance, they used a mixture of real and imitation blood, molasses, semen, soil, and sweat as their material to sketch the mural. These disparate fluids conjure up real and inferred elements of Ossorio's life. Take for example the molasses that would have been processed by the sugar factories on Negros Island, whose workers the chapel primarily served, or the bodily fluids that might have accompanied his artistic and personal frustrations at being back in the Philippines for the first time since he left as a child.

The transness of Lien and Camacho's mural extends excitedly into numerous other terrains and tributaries, including Ossorio's mixed-race family background, his diasporic dislocation from the Philippines to the United States, and his sexuality. Transcultural, transnational, and transgressing religion and sex, Ossorio never quite belonged to any fixed binary or conception of self. Likewise, Lien and Camacho's lecture notes can be read as an additive, irresolute map-in-progress, a stretchy synecdoche of Ossorio's lifeworlds that voraciously ingests stray nodes and perverse permutations.

\section{$\mathrm{NWD}$}

Speculatively linking a variety of writing styles and related propositions, from the intra-actions of electrons to lightning and queer kinship, theorist Karen Barad's writing performs the endless skies that gendered language offers. She consequently shows that matter, even at its most elementary and humble molecular level, is 'not the given, the unchangeable', but rather 'creatively regenerative, an ongoing trans*/formation'. ${ }^{2]}$ Likewise, through her Black Feminist Poethics, Denise Ferreira da Silva closely analyses the minute details of materials used in artworks. By reading art 'in the raw', in other words, through its rudimentary matter, she unshackles and 'corrupts the fixity' of critical commentary and liberal discourses that paradoxically insist on 
deterministic subjectivization. ${ }^{[3]}$ Barad and da Silva hypothesise how horizons can be mined from the most miniscule, ignoble fragment. Likewise, the artists discussed here show how a single word, (im)properly deployed and manipulated, can be that horizon for gendered life, one that exceeds its own regulation and purview.

\section{WWD}

Jamie Crewe will present work in 'Still I Rise:

Feminisms, Gender, Resistance, Act 2',

February 9-May 27, 2019 at De La Warr

Pavilion, Sussex, UK.

$B C E$, a collaboration between Sophia Al-Maria and Victoria Sin, will be on view January 12-April 28, 2019 at the Whitechapel Gallery, London, UK.

Amy Lien and Enzo Camacho's work is exhibited, December 1, 2018-February 10, 2019 at The Lab, NTU Centre for Contemporary Art, Singapore.

$\triangle W$

\section{Cite this piece as:}

Bing Hao, Wong. 'Territory: Universe (Translexical Opacity)'. The Contemporary Journal 1 (January 24, 2019). [https://thecontemporaryjournal.org/strands/on-t ranslations/territory-universe-translexicalopacity].

[1]

Amy Lien and Enzo Camacho on Alfonso Ossorio's Angry Christ mural, Lecture on December 1, 2018, The Single Screen, NTU Centre for Contemporary Art, Singapore.

[2]

Karen Barad, 'Transmaterialities: Trans*/Matter/Realities and Queer Political Imaginings', GLQ: A Journal of Lesbian and Gay Studies 21, nos. 2-3 (June 2015): 387-422. doi:10.1215/10642684-2843239.

[3]

Denise Ferreira da Silva, 'In the Raw', e-flux 93 (September 2018).

https://www.e-flux.com/journal/93/215795/in-the-raw/. 